International Journal of Linguistics, Literature and Translation

ISSN: 2617-0299 (Online); ISSN: 2708-0099 (Print)

DOI: 10.32996/ijltt

Journal Homepage: www.al-kindipublisher.com/index.php/ijltt

\title{
The Metamorphosis of the Tragic Hero - The Greek Classical and Post-Classical Renaissance in Contention
}

\author{
Asuamah Adade-Yeboah ${ }^{1}$ \& (D) , Edward Owusu ${ }^{2}$ (D) $\triangle$ and Kweku Rockson ${ }^{3}$ \& (D) \\ ${ }^{1}$ Senior Lecturer, Christian Service University College, Kumasi, Ghana \\ ${ }^{2}$ Senior Lecturer, Sunyani Technical University, Sunyani, Ghana \\ ${ }^{3}$ Senior Lecturer, Wisconsin International University College, Accra, Ghana
}

$\triangle$ Corresponding Author: Edward Owusu, E-mail: edwardowusu@minister.com

\section{ARTICLE INFORMATION}

Received: June 08, 2021

Accepted: July 14, 2021

Volume: 4

Issue: 7

DOI: $10.32996 /$ ijllt.2021.4.7.21

\section{KEYWORDS}

Classical, Renaissance, Morality theory, Aristotle, Hamartia, Oedipus and King Lear, Tragedy, Hero

\section{ABSTRACT}

Just as tragic heroes and heroines have been identified with different eras and cultures, the classical ideal of the classical and post-classical Renaissance will be incomplete if the concept of tragedy is not focalized. This paper, therefore, looks at how both periods delineated their tragic heroes, based on their actions portrayed in the plots of their plays. The paper, using textual analysis, provides extracts from William Shakespeare's King Lear, as the main text to present King Lear as the postclassical tragic hero. This is juxtaposed with extracts from Sophocles' King Oedipus, as the main text, and Euripides' Iphigenia in Tauris, as a hero supporting text to present Oedipus as the classical hero. Whereas textual analysis shows that the delineation of the tragic hero lies in the source of the tragic situation - the concept of hamartia of the classical period, the post-classical Renaissance period portrays the tragic hero on the basis of the weakness of character.

\section{Introduction}

Tragedy as a thematic genre is a test exhibited in drama in that, tragedy is of action and not character as Aristotle puts it. This assertion by Aristotle had its root in the Greek at the time drama was at its peak. The tragic drama of Aeschylus and those who came after him from the Ancient dithyramb, choral songs were chanted in humour of Dionysus. However, in the $6^{\text {th }} \& 7^{\text {th }}$ centuries BC, some changes were seen in the earlier development. This included the separation of the choral leader from the crowd, making it possible for dramatic action which was lacking. The prolific tragic dramatist Sophocles and Euripides wrote to show the skills at the time when old legends were considered skeptical because the goals were no longer the powerful forces to reckon with.

Contrary to the Greek classical period where tragedy is not born out of moral flaw (character), in the post-classical Renaissance, the tragic hero's character is the crux of the matter. The underlying reason is that 'hamartia' as interpreted by Aristotle regarding tragic hero, has gone through metamorphosis.

The brain behind this, are Italians scholars of the period who misrepresented the hamartia and translated it as "a weakness of character". In the place of this, they propounded the "moral theory" and made it crucial to the reading of tragic hamartia as being situated in character of the hero. This popularized the tragic flaw theory and was the order of the day in characterizing the posts-classical Renaissance tragic hero.

According to Ludowy (1977), Elizabethan plays were based on the ideas of the wheel of fortune and the fall of princes and the English tragic hero was further influenced by Machiavelli. Roche (1981) contends that the play King Lear is meant to show the plight of a man in pre-Christian times and that Shakespeare has had to make changes in the play to give it the required shape.

$\begin{array}{lllll}\mathbf{K} & \mathbf{C} & \text { AL-KINDI CENTER } \\ \mathbf{R} & \mathbf{D} & \text { FOR RESEARCH AN }\end{array}$ R D DEVELOPMENT Your gateway to world-class research

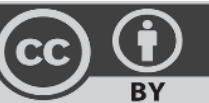

Published by Al-Kindi Center for Research and Development, London, United Kingdom. Copyright (c) the author(s). This open access article is distributed under a Creative Commons Attribution (CC-BY) 4.0 license 
Adade-Yeboah and Amankwaah (2012) define tragic knowledge as "a set of critical assumptions about the triumph of the tragic hero in defeat". They further posit that, "a tragic hero attains a kind of knowledge that redeems him from his suffering and reconciles his claims to the world he leaves impoverished for his loss." Aristotle stands tall as a candle lit on a mount among those who have said tragedy is a literary form. In his book "The Poetics (1963), Aristotle posits:

There remains then the man who occupies the mean between saintliness and depravity. He is not extraordinary in virtue and righteousness. And yet does not fall into bad fortune because of evil and weakness but because of some hamartia of a kind found in men of high reputation and good fortune such as Oedipus and Thyestes..."

The critical word is "hamartia" which interprets "going wrong" which the Greeks point out as the proper tragic situation. It is considered an impetuous act and has no malice. A critical analysis brings to light that "hamartia" is of action and plot and not of character. However, the Renaissance critics and commentators who first saw the original Greek text of "The Poetic" translated Greek hamartia in respect of the tragic hero to mean "a weakness of character".

\section{Method/Approach}

Among the various Greek cultural productions, their tragedy offers the most welcoming approach to their spiritual contribution in the same sense that tragedy fuses high art with profound thought. Nevertheless, to judge ancient tragedy by appropriate thermometers to the modern era can be misleading because of the different premises and objectives of the Greek plays. This is what Hamersley (2008) has to say in this regard:

The task is not just to produce a reading of a particular "text" but also to use this to illuminate general issues about human life.

This paper delves into the selected plays, using the method of close reading of textual analysis approach for the purpose of an effective presentation of this comparison of these two heroes of different eras. McCaw (2008), Atkin (1983) and Adade-Yeboah \& Ahenkora (2012) amply use this method to perfection. With this closeness and systematic observation of the texts as Brown (1990) observes will not limit the opportunities available for effective performance. It will make the relationship a more lively and the most provocative feature of a dramatic work.

\section{Analysis and Discussions}

\subsection{The Plot and the Imitation of Action}

The Greek drama grew out of religious rituals and presented as part of a religious cult. This is linked up with the place and occasion of presentation which control the structure of play and presentation mode. The plots of the tragedies were mostly drown from the great body of traditional myths. The sources have only skeletal frame of information and the dramatics proceed to show the character and motivation of personages who could so behave and what their behaviour can mean to the rest of us. All the principal personages must be of us. Oedipus in King Oedipus as a classical example of a tragic character and of a tragedy is evident in the citation of Warrington (1965) from Aristotle:

The imitation of an action that is serious has magnitude and is complete in itself; in language with pleasurable accessories... with incident arousing pity and fear, whereby to provide an outlet for such emotions.

What it means is that, tragedy is an "action that is serious". This action must be tied up with the plot because the plot is the imitation of the action which is the synthesis of the individual acts. The action must be serious because it must bother on a person of high class - an aristocrat. This action must also call for attention through dramatization and not necessarily in narration. From the above description, it is clear that Oedipus, in King Oedipus befits the description because he is of noble birth but whose ignorance made him commit incest and patricide. Another element to consider is their completeness of the action which has a beginning, middle and an end. This is what Adade-Yeboah, Ahenkora and Amankwah (2012) have to say:

A beginning is what does not, of necessity, come after something else but which something else naturally happens. An end, on the contrary, is that which necessarily happens after something else, but which has nothing after it; and middle is that which has come after something and it has something after it.

As a result of this, the plot should neither begin where they neither chance to nor end where they chanced to, but to conform to the above. Therefore, it is not surprising that Oedipus' birth and growth in the house of Merope and Pelops; the killing of king Laius, and the solution to the riddle of the monster are all outside the plot. Euripides' Iphigenia in Tauris has this kind of plot.

In this play, we see Iphigenia's sacrifice of blood to Artemis of Aulis through Odysseus' craft is made abortive through Artemis by stealing and replacing her with a deer. This account is not found in the plot, but can be found in Greek mythology. Sophocles, for 
example, makes the beginning of the play where Oedipus assumes his kingship on the Theban land, while Euripides begins the play at Tauriland where Iphigenia is taken to be a priestess. Both playwrights artistically weave these myths into the drama.

On the other hand, Shakespeare's post-classical renaissance conceives King Lear in the context of original sin rather than "hamartia" of king Oedipus. In King Oedipus, the tragic hero has no tragic flaw. Thus, any flaw he may have in his character is not tragic, in the sense that it is not made directly responsible for the tragic situation.

Contrary tragic flaw is a common feature of most Elizabethan protagonists. Hence, in King Lear, we see Cordelia return to England just in time to arrest her father's slide into disease and unhappiness. In the post-classical Renaissance period, tragedy still tells the story of a fall of a Prince like King Lear, but the difference here is that the Renaissance story is without hamartia and the element of fate (Moira) which is crucial in the case of Sophocles' Oedipus. King Lear can be seen to have been personally responsible for his fall.

Roche (1981) observes that the play is meant to show the plight of man in the pre-Christian times and that Shakespeare has hard to make changes in the play to give its required shape. Roche's contention is that, without the Christian dimension to the pagan tragedy, the reconciliation between Lear and Cordelia cannot be possible. In this direction, Lear thinks that in dividing his kingdom, he hopes for the best but realises that it is impossible.

\subsection{The Tragic Source/Situation}

In the classical period, the tragic situation is where the tragic hero is presented as a man of high integrity and unyielding in purpose but subject to the normal frailties of the human being. He is given to making rush decisions with the aim of being zealous to do the right thing.

Nonetheless, the tragic source of situation of Oedipus is not his temperamental disposition. For example, the killing of his father can be attributed to a number of factors, including ignorance and temper. However, the incest committed is not attributed to Oedipus' moral weakness.

Above all, he is a good king in whom his subjects repose confidence. The faith Thebans have in him springs from the fact he is the stranger who came to Thebes to solve the problem of the Sphinx and to free their land from the plague. For his reward, he is given the Theban crown and their widowed queen who is offered to him in marriage. Oedipus is seen to demonstrate his intellectual arrogance in his action, a fact which makes him hubristic.

As he casts his mind back to his defeat of the Sphinx, he feels intellectually equal to the present problem and rightly assumes his capability to solve it. In this regard, he sends Creon to the Delphic oracle to ask what could be discerned from Apollo, only to be told that the murderer of King Laius resides in their midst.

As a result, this suspense is one of the main features of the play that makes the play eminent. Oedipus, who is ironically tasked to find the murderer and to meet out the prescribed punishment, pronounces a curse and desolation on the unfound culprit and on himself:

I here pronounce my sentence upon his head: No matter who he may be, he is forbidden shelter or intercourse with any man...Expelled from every house, unclean, accursed in accordance with the word of Pythian oracle (1. pp. 235-242).

This speed does not only depict Oedipus' earnestness and overzealous nature to get things done, but get them done well. A job well done is profound source of pride to him. He, therefore, anticipates the end and assures his subjects. Oedipus starts the journey to his own destruction - the journey into darkness and desolation. Tieresias aptly puts it thus:

Then hear this: upon your head is the ban your lips have uttered... you are the cursed polluter of this land. (1. pp. 382 - 384).

The prophecy of condemnation from Teiresias which is not taken seriously especially Oedipus and anybody else is quite an unexpected turn of event and an absolute surprise as well as bewilderment even to the chorus who firmly believes and upholds the infallibility of the gods. The gods set the trap for Oedipus and we cannot blame him for what he does.

The same plot structure influences Euripides' Hippolytus (1965). In this drama, Theseus murders his son in ignorance of his son's true virtue. Hence, Theseus' action is seen as a hamartia and not a character trait. This, Artemis affirms in the exoneration of Theseus:

His death was not yours, men may well commit hamartia when the gods so ordain. Invariably, we see that the goddess distinguishes the doer from the deed and blames an external force rather than depravity. Similarly, the character and action of 
Phaedra (whose incestuous relationship with her step son), should be viewed as an external madness rather than internal weakness of character.

Much like Euripides, Aeschyhus and Sophocles never intend their tragic heroes to fall into misfortune because of evil and wickedness caused by a defect in character. Greek tragedy as Adade-Yeboah et al. (2012) put it, "character is not essential element because it is not conceived that way".

Aristotle observes four necessities of the tragic character: good morals, appropriateness, true to life or to the mythical prototype, and consistency. A tragic flaw or moral weakness of character has none of the above requirements nor does it have any implied meaning. Therefore, where Oedipus is heard saying, "my skill has brought me glory", he is not displaying arrogance as a character trait but showing his ability as a leader and a man of intellect. Paradoxically, Oedipus lacks an insight into Teiresias speech: And this success brought you ruin too. Styan (1960) poists:

Truth can save or destroy; we continue; Oedipus will find inside when he loses his sight, but his new knowledge will destroy, and in destroying him, may save him. In bearing his shame, he will live again with truth, and both his destruction and salvation will depend upon his accepting his shame and his penance of his sin. Oedipus wills his life to find it.

This extract amply demonstrates in the life of the tragic hero because Oeidus gains insight in his sightlessness when the situation takes a different turn, after the revelation. Nonetheless, we find the greatest of a man who is noble because of his readiness to accept and atone for his sins. Oedipus, the proper hero who must not be a coward rather urges the shepherd to disclose the "dreadful tidings":

And I am about to hear them. But hear them I must. (1, p. 1125).

On the contrary, the tragic source of King Lear of the Post-Classical Renaissance, is his tragic flaw who represents human frailty. Even though the classical Greek structure gives it an appearance of a pagan tragedy, "King Lear" is a Christian in spirit. Lear, in the opening lines of the play sets in motion that which leads to his tragedy. He demons that his three daughters; Goneril, Regan and Cordelia prove there filial, fidelity and love:

Which of you shall we say that love us most? That we our longest bounty, may extend where nature dolt with merit challenge (1.i. 51-53).

King Lear proves to be a gullible parent eager to believe any show of affection and is consequently taken in by flattery of Gonaril who says to her father:

Sir, I love you more than the world can yield the matter.

In the same vein Regan pours out her heart in flattery:

I am made that self mettle as my sister and prize me at her worth... only she come too short, that I profess.

(1.1 69 - 72).

On the contrary, the king spurns the honest declaration of Cordelia. Her attempts at rationality go sorely against the grain; and therefore, she loses her inheritance to her two sisters. He openly tells Cordelia:

Here I disclaim all my paternal care propinquity and property of blood and as a stranger to my heart and me (1.i 113 - 115).

Cordelia is, thus, given to marriage without a dowry against Cordelia's honest declarations. Lear's uncanny vulnerability stems out of the two provocative statements earlier made in the play that lead us beyond the immediate dramatic ambiance are very pertinent. The first is Gloucester asking to kiss the hand of Lear, and the answer Lear gives is:

Let me wipe it first, it smells of mortality (4.vi 132).

To this, Gloucester replies:

O ruined piece of Nature! This great world

shall so wear out to nought (4.vi. 133 - 134).

From these speeches, we see Lear's display of an uncanny vulnerability in emphasizing his mortality, Gloucester generalizes on a fallen (ruined) nature betraying itself to nought (with a pun on naughtiness): 
In Lear and his court, Shakespeare characteristically blends elements of "British mythology, medieval feudalism, and Renaissance benevolent despotism to create a composite image of an older order which exists in mystic communion with God and with the order of the Cosmos" (Kerman, 1981)

Here, the spectacular tragedy is derived from Lear's endurance and resistance, both so mighty that they summon forth ultimate force or violence. He experiences the universe at a depth and height that sweeps away all lesser considerations.

Weiss (2008) view of the tragedy of Lear is that, while force is on our side, it is delectable but once it cannot make use of us, it tosses us aside; patience or resignation seems to be the only resort. The presentation of tragic hamartia where the tragic suffering is abundantly clear is best found in "King Oedipus" which has no equal in the Greek classical period.

The wrong actions of Oedipus bring on certain blindness, which is not an inward blindness of disposition but blindness of perception. Stated differently, the tragic suffering which occupies attention in this kind of tragedy is not as a result of moral blindness but emanates from an external incapacity due to ignorance. Therefore, the fall of Oedipus is his hamartia. Sackey (1992) aptly states:

"Aristotle's hamartia is simply a going wrong (not being wrong), for that will be an error of character which is (untragic) when the character is either ignorant of the particular wrong he is committing (like Oedipus killing his father and marrying his mother in ignorance) or act in the heat of passion (like Oretes killing his mother to revenge his father's death). Under these circumstances, Greek society prescribes appropriate sanctions against the culprit to right the wrong done".

A tragic hero, by hamartia brings a dislocation of the natural order.

\section{Conclusion}

Even though the causes of tragedy are due to Lear's inability to see through flattery and his hubris, there is also the suggestion of hamartia. This is because his first act, the decision to divide and share the kingdom, is wrong, though his character plays a major role in this. However, this action is not the dominant of a tragic situation. Unlike "King Oedipus" the source of the tragic situation is clearly traceable to Lear's moral flaw, Oedipus and Lear have similarities. Their suffering is both physical and mental attended by torture and deprivation, as well as exposure to the vagaries of the weather after their unilateral rejection of shelter. The poignancy of Lear is heightened not only by the insanity of the king, but also the exposure to the ferocious elements of the stormy night.

The study identified the need to understand the portrayal of the tragic hero of the Shakespearean Post-Classical Renaissance. In both the classical and post-classical periods, tragedy still tells the story of a fall of a Prince. The difference is that the Renaissance story is without hamartia and the element of fate (moira), but these are crucial to Greek classical tragedy. The concept of fate (moira) in the Greek classical period gives way to Christian faith in the post-classical period. Shakespeare conceives of Lear in the context of original sin rather than the hamartia.

In an unusual way "King Oedipus" in its tragic clarity and purity enables us to experience tragic pleasure from the time of the Greeks, the concept of tragedy has been exhaustively analysed as a literary genre and satisfactorily justified as a philosophy. Sophocles, like the Greek writer and philosopher, has sought to relate the genre to actual life. It must be observed that the delineation of the tragic hero lies in source of the tragic situation. It is expected that tragedy, an artistic reflection of a collective religious experience, imitates the culture to which it refers.

Funding: This research received no external funding.

Conflicts of Interest: The authors declare no conflict of interest.

\section{References}

[1] Adade-Yeboah, A., Ahenkora, K., \& Amankwah, A. S. (2012). The Tragic Hero of the Classical Period. English Language and Literature Studies, 2(3), 10-17.

[2] Adade-Yeboah, A., \& Amankwah, K. (2012). The Tragic Hero of the Neo-Classical Period. International Journal of Humanities and Social Science, 2(14), 104-108.

[3] Allan, H. Gilbert. (1962). Literary Criticism: Plato to Dryden. Mayne State University Press.

[4] Aristotle (1956). On the Art of Poetry. Classical Literary Criticism. Penguin Books Ltd..

[5] Atkins, D. G. (1983). Reading Deconstruction: Deconstructive Reading. University Press of Kentucky.

[6] Brown, J. R. (Ed.). (1990). Studying Shakespeare: A Case Book. London. Education Ltd..

[7] Dorch, T. S. (1956). Classical Literary Criticism. Penguin.

[8] Euripides. (1965). Iphigenia in Tauris. Penguin Book Ltd.

[9] Fluchere, H. (1953). Shakespeare. Longman. 
[10] Hammersley, M. (2008). Questioning Qualitative Inquiry. Sage Publication Ltd.

[11] Hegel. (1962). Hegel Tragedy. New York: Anchor Press. International Journal of Humanities and Social Science, 2(5), $246-254$.

[12] Ludowyk, E. F. C. (1977). Understanding Shakespeare. Cambridge University Press.

[13] McCaw, N. (2008). How to Read Texts: A Student Guide to Critical Approaches and Skills. Continuum.

[14] Roche Jnr., T. P. (Ed.). (1981). Tragic Knowledge in King Lear. On King Lear. The University Press.

[15] Sackey, A. A. (1992). "The Hamartia of Aristotle", In The Dimensions of Comparative Literatyre. SMA.

[16] Shakespeare, W. (Ed.). (1670). King Lear. Penguin Books Ltd..

[17] Shakespeare, W. (Ed.). (1670).Othello. Penguin Books Ltd..

[18] Shakespeare, W. (Ed.). (1990). The Tragedy of Hamlet, Prince of Denmark. Longman.

[19] Sophocles, E. A. (1974). King Oedipus. Penguin Book Ltd.

[20] Styan, J. L. (1960). Elements of Drama. Cambridge University Press.

[21] Termizi, A. A., \& Ching, T. A. (2012). Helicanus as 'A Figure of Truth, Faith and Loyalty' in Shakespeare's Pericles.

[22] Warrington, J. (1965). The Poetics by Aristotle. J.M. Dent \& Sons Ltd.

[23] Watling, E. F. (1974). The Thebian Plays by Sophocles. Penguin Books.

[24] Weiss, T. (2008). The Poetics of King Lear. John Murray. 